\title{
THE ORGANIZATION AS WEAPON IN WHITE-COLLAR CRIME $\dagger$
}

\author{
Stanton Wheeler* \\ Mitchell Lewis Rothman**
}

Edwin Sutherland originated the phrase "white-collar crime" in his presidential address to the American Sociological Society in December 1939,1 but scholarly consideration of the subject precedes that date considerably. In 1907, while the muckrakers were publicizing corporate misbehavior for the masses, Edward Alsworth Ross published academic sociology's first treatment of what we today label white-collar crime. His Sin and Society argued that a new criminal was at large, one "who picks pockets with a railway rebate, murders with an adulterant instead of a bludgeon, burglarizes with a 'rake-off' instead of a jimmy, cheats with a company prospectus instead of a deck of cards, or scuttles his town instead of his ship ${ }^{2}$-in short, one whose crimes were committed on behalf, or with the assistance, of a business corporation.

Like Ross, Sutherland wrote primarily of corporate illegality; his study of offenses committed by seventy of the nation's industrial leaders, presented at length in White Collar Crime, ${ }^{3}$ informed all his work. ${ }^{4}$ Sutherland's most widely accepted definition of white-collar

$\dagger$ With compliments for unwittingly suggesting the title: Philip Selznick "(The Organizational Weapon) and Frank Zimring ("The Medium Is the Message: Firearm Caliber as a Determinant of the Death Rate From Assault") 1 J. LEGAL STuD. 97 (1972). This work is supported by Grant \#78-NI-AX-0017 from the National Institute of Justice, U.S. Department of Justice. Points of view or opinions in this document are those of the authors and do not necessarily reflect the official position or policies of the Department of Justice. We are extremely indebted to two principal collaborators on the white-collar crime project, Nancy Bode and David Weisburd, who were responsible for much of the original data collection and analysis. We would also like to thank Jack Katz, Reinier Kraakman, Woody Powell, and Albert J. Reiss, Jr. for helpful comments on an earlier draft.

* Professor of Law and Sociology, Yale University. B.A. 1952, Pomona College; M.A. 1956, Ph.D. 1958, University of Washington.

** B.A. 1969, Queens College; J.D. 1974, Ph.D. 1982, Yale University. Assistant Professor of Law, Hamline University.

1. Published the following year as Sutherland, White-Collar Criminality. $5 \mathrm{AM}$. Soc. REv. 1 (1940). Sutherland had used the phrase "white-collar criminaloids" in the second and third editions of his text, PrInCIPLes of Criminology $(1934,1939)$.

2. E. ROSS, SIN AND SOCIETY 7 (1907).

3. E. SutherLand, White-Collar Crime (1949).

4. See Crime of Corporations, in The Sutherdand Papers 78-96 (A. Cohen, A, Lindesmith \& K. Schuessler eds. 1956); The White-Collar Criminal, in Encyclopedia of Criminology 511-15 (V. Branham \& S. Kutash eds. 1949); Is "White-Collar Crime" Crime?, 10 AM. 
crime, however, said nothing at all regarding corporate or organizational conduct. Instead, it spoke of status and occupation, grafting new themes to sociology's traditional concern for corporate excess: "White-collar crime may be defined approximately as a crime committed by a person of respectability and high social status in the course of his occupation." 5

Though important, the link between social status and white-collar crime is not immediately relevant. What is significant is how deference to a requirement that the white-collar criminal act "in the course of his occupation" and the notion that white-collar crime is inherently organizational have been sources of ambiguity and confusion in the literature since Sutherland's death. Two influential works, Clinard's ${ }^{6}$ and Hartung's' ${ }^{7}$ research on black market activities during World War II, are revealing in this regard. Both studied the crimes of businesspeople. Both suggested that white-collar crime referred only to such conduct. But for Clinard, white-collar crime meant only "illegal activities among business and professional men,"8 while Hartung viewed it as "a violation of law regulating business, which is committed for a firm by the firm or its agents in the conduct of its business."

This tension between one view of white-collar crime focusing on occupation and another emphasizing organization was not soon resolved. During the 1960 s and early 1970 s, researchers either viewed occupational and organizational illegality as distinct forms of criminal behavior, or described corporate offenses as a subset of occupational illegality. Reflecting the first point of view, for example, a leading text presented separate chapters on occupational and corporate offenses. Occupational crimes, it stated, include those "committed by individuals for themselves in the course of their occupations and the offenses of employees against employers"; corporate offenses were those "committed by corporate officials for their corporation and the offenses of the corporation itself." 10 But these were distinctions without a difference. How is one to determine when crimes are committed "for the corporation" or by "the corporation itself"? In-

Soc. REv. 132 (1945); White-Collar Criminality, supra note 1; Crime and Business, 217 ANNALS 112 (1941).

5. E. Sutherland, supra note 3, at 9 (footnote omitted).

6. See M. Clinard, The Black Market (1952); Clinard, Criminological Theories of Violations of Wartime Regulations, 11 AM. SOC. REV. 258 (1946).

7. Hartung, White-Collar Offenses in the Wholesale Meat Industry in Detroit, 56 AM. J. Soc. 25 (1950).

8. M. Clinard, supra note 6 , at viii.

9. Hartung, supra note 7, at 25 (footnote omitted).

10. M. Clinard \& R. Quinney, Criminal Behavior Systems 188 (2d ed. 1973). 
cluding organizational offenses within a larger category called occupational crime, as some writers have done, does not make the line between the two any easier to draw. ${ }^{11}$

Previous work has tried to distinguish individual and organizational illegality in two ways. One approach focuses on benefit: Either the individual gains at the organization's expense, as in embezzlement, or the organization profits regardless of individual advantage, as in price fixing. ${ }^{12}$ But individuals and their organizations often reap mutual advantage from criminal conduct. What happens, for example, when white-collar crimes are committed by the principals of small business firms? In such instances, it may be misleading to speak of separate individual and organizational identities; motive may reflect individual as well as organizational interests.

The second approach asks whether criminal behavior furthers organizational goals. ${ }^{13}$ Again, we run into difficulties. Stated objectives may not correspond to organizational reality, and groups within a firm may favor widely divergent aims. In an analysis developed for other purposes, Ermann and Lundman have suggested that information concerning organizational norms, socialization patterns within the enterprise, and executive knowledge of subordinates' activities are all required before wrongdoing can be classified as individual or organizational. ${ }^{14}$ It is often difficult, of course, to obtain such data.

The recent explosion of interest in white-collar illegality has not greatly changed matters. Scholars have concentrated on corporate crime and given less attention to illicit occupational behavior, but it is still not clear whether research refers specifically to organizational or occupational offenses or to some combination of these phenomena. That the two categories might overlap is often ignored; after all, those who act on behalf of an organization generally do so in an occupational role. On the other hand, occupation inplies employment and in our society most employment occurs within an organization. Unfortunately, no one has specified what difference it makes

11. See Clarke, White-Collar Crime, Occupational Crime, and Legitimacy, 6 INTL. J. CRIMInology \& Penology 121 (1978); Hornung, Blue-Collar Thefi: Conceptions of Property, Attitudes Toward Pilfering, and Work Group Norms in a Modern Industrial Plant, in CRIMES Against Bureaucracy 46, 47 (E. Smigel \& H. Ross eds. 1970).

12. H. Bloch \& G. Geis, MaN, Crime, and Society (1962); M. Clinard \& R. Quinney, supra note 10 , and Hartung, supra note 7 , have all employed this distinction.

13. See Schrager \& Short, Toward a Sociology of Organizational Crime, 25 Soc. PRoBs. 407 (1978); Shapiro, Thinking About White-Collar Crime: Matters of Conceptualization and Research, in RESEARCH ON WHITE CollaR CRIME (National Institute of Justice, U.S. Department of Justice) 1980.

14. Ermann \& Lundman, Deviant Acts by Complex Organizations: Deviance and Social Control at the Organizational Level of Analysis, 19 Soc. Q. 55 (1978). 
when a crime is committed under the cover of an organization or in some occupational context. And social scientists and legal scholars have referred only to the largest, for-profit corporations in describing - and decrying - the consequences of organizational wrongdoing.

This Article explores the advantages of using organization or occupation in the more typical case. Our inquiry takes this as its central question: What difference does it make when a white-collar crime is committed in the course of one's occupation or when acting on behalf, or with the assistance, of an organization? If we are becoming, as some have argued, an organizational society, ${ }^{15}$ then we should see the results of this change reflected in illicit as well as licit behavior. The organizational form may be used for either social or antisocial ends. Our principal hypothesis, as the title suggests, is that the organization, size and profitability notwithstanding, is for whitecollar criminals what the gun or knife is for the common criminal a tool to obtain money from victims. ${ }^{16}$

\section{Design of the INQUiRY}

Our work was part of a broader program of research on whitecollar illegality. ${ }^{17}$ Specifically, our data were drawn from a study assessing differentials in the sentencing of white-collar offenders, which had collected presentence investigation reports (PSIs) for persons convicted during fiscal years 1976, 1977, and 1978 of eight presumptively white-collar crimes prosecuted in the federal courts:

15. Our society is an organizational society. We are born in organizations, educated by organizations, and most of us spend much of our lives working for organizations. We spend much of our leisure time paying, playing, and praying in organizations. Most of us will die in an organization, and when the time comes for burial, the largest organization of all-the state - must grant official permission.

A. EtzIONI, MOdern ORGanizations 1 (1964) (footnote omitted). The phrase itself is drawn from the larger discussion in R. Presthus, The Organizational SocietY (1962).

For Perrow, the word "organization" no longer qualifies "society" - organizations are society. In our "society of organizations," the organization is "the only game in town," the locus of "almost all human needs, including the numerous ones it has managed to create." Today, virtually all that is human is created in or defined in terms of its association with organizations. Organization Theory in a Society of Organizations (1979) (paper delivered at the annual meeting of the American Sociological Association, Boston).

16. The organizational advantage should obtain when not-for-profits step over the line, too. But our data so infrequently include the activity of not-for-profit organizations that we are loathe to generalize about such conduct. Nevertheless, we use both "corporate" and "organizational" (and related forms of these words) throughout to connote phenomena more universal than those occurring only in for-profit, commercial contexts.

17. Books published so far in this program include W.M. Reisman, Folded Lies (1979), and S. Rose-ACKerman, Corruption: A Study in Political Economy (1978). Another six studies will be forthcoming from Yale University Press as they reach completion. They will include monographs on self-dealing in the corporation, detection of illegalities by the SEC, federal prosecution of white-collar crime, legal defense of white-collar defendants, and two studies of sentencing of white-collar offenders. 
antitrust violations, securities fraud, postal and wire fraud, false claims and statements, credit and lending institution fraud, bank embezzlement, tax evasion, and bribery. This sentencing project had studied as many as thirty cases per offense in each of seven federal districts $^{18}$ for six of the categories of crimes, and a national sample of antitrust and securities cases.

Prepared by federal probation officers, the PSI is the basic document used by the court at sentencing. ${ }^{19}$ For cases that have not gone to trial (eighty-two percent of those in our sample), the PSI is often the only source of information regarding offense and offender available to the judge. That presentence reports are completed for only a few of those who actually commit illegal acts is, of course, significant. Criminal activity not discovered or reported to authorities was not in the sentencing project's sample. Neither was conduct that did not result in indictment or, eventually, a finding of guilt. The cases examined were thus not representative of even the eight federal crimes under scrutiny. ${ }^{20}$ Consider, for example, the effect of prosecutorial decisions on case selection. It has been suggested the results reported below in part reflect features of the enforcement process; organizational crimes, it is said, are difficult to prove, and prosecutors make the unusual investigative effort required to document organizational illegality only when wrongdoing is prominent enough, in terms of structure, duration, victimization, and the like, to warrant massive investment of time and other resources. Less consequential misbehavior simply isn't "worth it." We disagree with that argument, and shall return to the issue after presenting our own findings, but we do think it worth keeping such possibilities in mind as the data are reviewed.

Because it provides descriptions of the nature of the crime and the context in which it was carried out, the PSI permitted the identification of offenses committed by individuals, those committed by individuals who used an occupational role or position, and those accomplished through some form of organization. Our defendants fell

18. The districts (and their central cities) include Central California (Los Angeles), Northern Georgia (Atlanta), Northern Illinois (Chicago), Maryland, Southern New York (Manhattan and the Bronx), Northern Texas (Dallas), and Western Washington (Seattle).

19. Rule 32(c)(1) of the Federal Rules of Criminal Procedure requires a presentence investigation report to be made out on all convicted offenders prior to sentence unless, with the court's permission, the defendant waives the report, or the court finds sufficient information in the record to sentence the offender. Approximately six percent of our potential sample cases had no PSI. As a condition of receiving these confidential documents, we agreed with probation authorities to establish procedures to insure confidentiality of personal information.

20. Much less behavior was prosecuted in other statutory categories or in state courts. 
into the six categories shown in table $1 . .^{21}$

Table 1

\section{A Typology of White-Collar Offenders}

Offense

Use of an Occupational

committed by:

Role or Position

\begin{tabular}{lll} 
A Single Individual & $\underline{\text { NO }}$ & $\underline{\text { YES }}$ \\
\hline A Group of Affiliated Individuals & Cell 2 & Cell 4 5 \\
\hline Through Use of a Formal Organization & Cell 3 & Cell 6 \\
\hline
\end{tabular}

The presentence reports were completed for individual defendants. ${ }^{22}$ Though we refer throughout to occupational and organizational crimes, it is perhaps more accurate to say that we are really concerned with the benefits accruing to individuals as a result of the use of occupation and organization. We have already indicated that differentiating between individual, occupational, and organizational offenses is not an easy conceptual matter. It is often not possible to separate individual and organizational gain neatly, or to distinguish the influence of occupational role and organization on criminal activity when persons are operating in complex social environments, and we make no attempt to do so here.

After a preliminary examination of the data, we made two changes in order to simplify the presentation here. First, we collapsed the distinction between individuals operating alone (cell 1) and individuals acting with affiliated persons (cell 2). As we anticipated, on most items the category of "affiliated individuals" falls between lone defendants on the one hand, and those using an organizational position on the other. But since there is not much difference between "affiliated individuals" and lone offenders, and

21. Two items from our coding scheme were used to establish the three fold typology described below. One item asked: "Which of the following comes closest to describing the level of organization of the actual offense?" The three relevant categories turned on whether the offense was committed by a single individual, by two or more affiliated persons, or "through an organized association, business organization, partnership or family business." The second category indicated use of the combined personal resources of several individuals working in an informal group; the third marked the defendant's mobilization of the resources of a formal organization. The second item used to construct the typology asked: "What role did the defendant's occupational situation play in the offense?" Although the coding scheme allowed for a variety of modes of use, we distinguished simply between those in which the defendant's occupational situation played no role and those in which it played some part - permitting access to documents or information, the use of a position of authority or business identity to victimize others, and the like.

22. Because it was particularly interested in the decision to incarcerate, the sentencing program did not focus specifically on indicted organizations. In fact, with the exception of antitrust, where corporations are routinely named, organizational indictments occur only infrequently in these statutory categories. 
the number of cases in the affiliated category was about half the other, we saw no reason to separate rigorously the two in this paper.

The second major simplification pertains to cell 3: individuals who use organization, but not occupation. This Article will not discuss these cases. This cell was by far the smallest, comprising less than four percent of the sample. We considered joining these cases with cell 6 , or with the now united cells 1 and 2 , but after inspecting the cases decided not to, for they seemed to fall into distinct types and did not allow for easy combination. ${ }^{23}$

We have, then, three principal categories of offenders: those who committed offenses alone or with affiliated others using neither occupational nor organizational role (individual offenders); those who committed offenses alone or with affiliated others using an occupational role (occupational offenders); and those who committed offenses in which both organization and occupation were ingredients (organizational offenders). ${ }^{24}$ Note again that we did not distinguish occupational and organizational crimes. Rather, we considered occupation and organization as attributes that may - or may not appear in a given instance. Note, too, that our organizational crimes need not be the result of corporate misadventure (though most of the organizational illegality reported below was committed by, or on behalf of, for-profit business organizations). We expected that crimes committed within an occupational role would differ from crimes that were not, and that crimes committed with the assistance of both occupation and organization would be different still. By drawing on data collected by the sentencing project regarding the nature, consequences, and processing of white-collar illegality, and the personal and social characteristics of convicted white-collar felons, we hope to demonstrate how such differences are manifested.

23. Nearly one half of these cases represented instances of tax evasion, where either an employer failed to remit taxes withheld from workers' paychecks, or self-employed persons did not report business income on their personal returns. The second largest category in the cell included cases of fraud where defendants operated in shell or other alleged corporations.

24. The face validity of this measure - how well it reflects distinctive occupational and organizational qualities - is suggested by its relation to two other indicators of level of organization used in our study. We asked whether an offense occurred once, on a number of separate occasions, on separate occasions, but as part of one overarching plan, or whether it had one cumulative effect. As expected, this variable is strongly related to organizational type: Of the offenses occurring only once or on a number of separate occasions, about one half were individual offenses (compared to $36 \%$ for the total sample). Of those that involved an overarching plan or added up to one cumulative effect, about one half were committed through an organization, compared to $35 \%$ for the total sample. Similarly, we coded the data to determine whether an offense involved one level of organization, two levels of organization, or three or more levels. Seventy-seven percent of the individual or affiliated individual cases involved one level only, in contrast to less than $25 \%$ of those where both occupational and organizational roles were present. 
One final methodological note before we present our results. By combining defendants convicted of different statutory offenses, we necessarily neglected features that were offense-specific. Within our sample, for example, most bank embezzlers were individual offenders using an occupational position, and most tax offenders were individuals who had neither occupational nor organizational "cover." At the same time, both an organizational and occupational role were involved in all the antitrust cases and most of the SEC cases. Thus, we might attribute to the "organizational" dimension something that is specific only to a particular offense such as SEC fraud or antitrust, to the "occupational" dimension something specific to embezzlement, and to the "individual" offenses something peculiar to tax fraud. To minimize this potential for distortion, we examined the relationships reported below both for the total sample, and for the four offenses - mail fraud, bribery, credit and lending institution fraud, and false claims and statements - that were spread fairly evenly across our three offender categories. ${ }^{25}$ We found that the relationships discovered in the full sample were virtually the same in direction, though somewhat smaller in magnitude (typically about half as strong), in the four-offense subset. We feel confident, therefore, that we are describing genuine effects of organizational and occupational role and not traits uniquely explained by a particular type of offense. In what follows, we will present results for the total sample, and will add necessary detail with regard to the subset if it appears that not doing so would distort the true picture.

\section{RESULtS}

\section{A. The Nature of the Illegality}

We explored the nature of illegal behavior in our sample by using two different kinds of indicator: The first are "ecological" measures describing the frequency, duration, and geographic spread of the offense. As the top portion of Table 2 shows, occupational and organizational offenders break the law more often before they are caught than do individual offenders. The differences are even clearer for our subset of four offenses. ${ }^{26}$

25. Each of these offenses has at least one fifth, and no more than one third, of its cases in each of the three categories.

26. Measurement of the number of acts may understate actual differences. For example, one price-fixing scheme was counted as a single act, even though dozens of overt acts in furtherance of the conspiracy might have occurred, or thousands of transactions with consumers taken place as a result. Similarly, a mail fraud scheme in which fifty orders were sent out in two mailings was coded as two acts, rather than one hundred. Recording numbers of discrete acts must to some extent remain problematic when offenses, theinselves so different, can be conceptualized in various ways. 
Table 2

Number of Times the Illegality was Completed All Offenses

Number of Cases Mean Number of Times

I. Individual Offenders
II. Occupational Offenders
III. Organizational Offenders
The Subset of Four Offenses

396

273

334

7.4

11.9

12.2

I. Individual Offenders

II. Occupational Offenders

III. Organizational Offenders

234

110

107

With respect to the duration of the offense (the length of time between the first act and the last), however, Table 3 reveals a substantial difference when we contrast the total sample with the more restricted set of four; results in the full complement of eight reflected the extreme length of most antitrust and SEC offenses (approximately five and three years, respectively). The longer duration for individual offenders and the shorter one for occupational criminals in the full sample are largely explained by the relatively prolonged nature of tax fraud, an individual crime, and by the comparative brevity of embezzlement, which is occupational. But the general pattern is very clear: Offenses committed in an organization's name occurred more frequently, and over a longer period of time, than those where an organizational element was lacking.

Table 3

\section{Duration of the Offense}

All Offenses

Number of Cases Mean Duration (in months)

I. Individual Offenders
II. Occupational Offenders
III. Organizational Offenders

$\begin{array}{ll}424 & 22.0 \\ 317 & 16.6 \\ 398 & 35.7\end{array}$

The Subset of Four Offenses

I. Individual Offenders

II. Occupational Offenders

III. Organizational Offenders

259

122

140
14.8

18.3

26.7

A similar picture emerges when we examine geographic spread. As Table 4 indicates, individual or occupational delicts are rarely felt outside the local area. Corporate offenses, however, are very likely to have effects spread far and wide. Individual and occupa- 
tional defendants may be distinguished at lower levels; those who use an occupational identity are more likely to affect at least a local area, not just immediate participants.

Table 4

The Geographic Spread of the Offense

\begin{tabular}{|c|c|c|c|c|}
\hline & $\begin{array}{l}\text { Individual } \\
\text { Offenders } \\
\end{array}$ & $\begin{array}{l}\text { Occupational } \\
\text { Offenders } \\
\end{array}$ & $\begin{array}{l}\text { Organizational } \\
\text { Offenders } \\
\end{array}$ & Total \\
\hline $\begin{array}{c}\text { Immediate Participants } \\
\text { Only }\end{array}$ & $\begin{array}{c}317 \\
(73.7 \%)\end{array}$ & $\begin{array}{c}174 \\
(52.1 \%)\end{array}$ & $\begin{array}{c}96 \\
(24.9 \%)\end{array}$ & 587 \\
\hline Local & $\begin{array}{c}76 \\
(17.7 \%)\end{array}$ & $\begin{array}{c}131 \\
(39.2 \%)\end{array}$ & $\begin{array}{c}75 \\
(19.4 \%)\end{array}$ & 282 \\
\hline State or Regional & $\begin{array}{c}13 \\
(3.0 \%)\end{array}$ & $\begin{array}{c}11 \\
(3.3 \%)\end{array}$ & $\begin{array}{c}92 \\
(23.8 \%)\end{array}$ & 116 \\
\hline National or International & $\begin{array}{c}24 \\
(5.6 \%)\end{array}$ & $\begin{array}{c}18 \\
(5.4 \%)\end{array}$ & $\begin{array}{c}123 \\
(31.9 \%)\end{array}$ & 165 \\
\hline Total & 430 & 334 & 386 & 1150 \\
\hline
\end{tabular}

The second group of indicators used to analyze the sample was more qualitative in nature. Three measures were employed to assess the complexity and sophistication of the crime. The first asked whether documents were created or manipulated during the offense to substantiate a false statement. Such activity is clearly linked to offense type: this occurred in a third of the individual cases, just over half of the occupational cases, and seventy percent of the organizational crimes. A pattern is less evident when the frequency of a "cover up" is examined. ${ }^{27}$ Fewer than one fifth of the solo offenders tried to hide what they had done; thirty percent of both the occupational and organizational defendants did so. Finally, the sentencing project's coders rated offense sophistication directly (if impressionistically). A one to four scale refiected whether illegal conduct was very, somewhat, not very, or not at all sophisticated. The mean rating for organizational wrongs was 1.9; for occupational crimes, 2.6; and for those conducted by lone men and women, 3.0.

The various indicators thus yield a relatively clear picture. While crimes committed in an occupational capacity are "larger" in some sense than those conducted outside such roles, the most dramatic effects are realized when occupational and organizational identities combine. This is quite consistent with other findings in our general research program which emphasize the ability to "hide" an offense within the interstices of organization and through elusive manipula-

27. The presence of cover-up activity was ascertained by asking, "Did the defendant employ methods to avoid or delay discovery of a previously committed illegality?" 
tion of paper, making it easier for relatively sophisticated crimes to continue undetected for a longer period and to occur with greater frequency. ${ }^{28}$

\section{B. The Economic and Social Consequences of Illegality}

The above results suggest patterned differences in the nature of the offenses undertaken by our three types of offender. We cannot, however, conclude from that evidence that the consequences of such acts are sharply different. For that we need evidence on the magnitude of the offense. In the course of our inquiry, we gathered from the PSI as much data as we could concerning the actual magnitude of the illegality in question - the "take," as measured in dollars. That information was often missing, particularly when, as in the more complicated mail and stock frauds and antitrust cases, the large number of victims made it very difficult to estimate total loss. The available data may, therefore, be biased in the direction of lesser amounts because we did not have full reporting in all instances. That the amount of loss is typically reported by either victims or governmental officials may compensate; both may have an interest in exaggerating offense magnitude. In any event, we regard the data presented below as crude, but think they are clearly adequate to show the main direction of the effect of organization, if not the precise degree of that effect. ${ }^{29}$

Because we believe the results are both interesting and important, and because we think different modes of presentation might lead to different conclusions, we present in Table 5 data for all of the surveyed offenses, as well as for the subset of four crimes. We also report separately the arithmetic mean, which heightens the significance of the very largest wrongs, and the median, or the case that lies precisely in the middle of the offense distribution. Indeed, because the means are so heavily skewed, we think that the medians convey the results most clearly. We also think it prudent to focus on the subset of four offenses, thus removing the particular effects of tax, bank embezzlement, SEC fraud, and antitrust cases. This leaves cases more evenly distributed across the four remaining crime categories.

28. See Katz, Legality and Equality: Plea Bargaining in the Prosecution of White-Collar and Common Crimes, 13 LAw \& Soc. REv. 431 (1979) (the complexity of white-collar crimes forces prosecutors to take more active roles in the investigation process).

29. Even where the data were available, the coding was not unambiguous. With bribery, for example, we coded the amount of the bribe or kickback, not the more speculative amount of the profit that might be gained as a result of the bribe. In income tax cases we coded the amount owed the IRS. For lending and credit institution frauds we coded the amount of loans applied for. For unsuccessful offenses (a very small portion of the total) we coded the amount that would have been taken had the crime been successful. 
Table 5

Offense Magnitude

All Offenses

I. Individual Offenders

II. Occupational Offenders

III. Organizational Offenders

The Subset of Four Offenses

I. Individual Offenders

II. Occupational Offenders

III. Organizational Offenders

\begin{tabular}{|c|c|}
\hline Number of Cases & Median Take \\
\hline $\begin{array}{l}316 \\
269 \\
221\end{array}$ & $\begin{array}{r}\$ 7,623 \\
\$ 8,018 \\
\$ 387,274\end{array}$ \\
\hline
\end{tabular}

Mean Take

$\$ 74,585$

$\$ 135,011$

$\$ 1,077,432$

$\$ 73,616$

$\$ 5,279$

$\$ 17,106$

$\$ 117,392$
$\$ 218,351$

$\$ 612,305$

Using either measure and in either sample, the results are stark and unmistakable. To begin, the median take for individual offenders in our subset of four offenses was a little over $\$ 5,000$. Those operating within the context of an occupational role netted approximately three times as much-a bit over $\$ 17,000$. If offenders used both occupation and organization to commit their offense, the take was about twenty times that in cases where they operated without such assistance. The corresponding median for all offenders was higher for individuals, reflecting primarily the addition of tax frauds (whose median was $\$ 21,668$ ); for occupational offenders it was only half as much as the median for the subset of four offenses (reflecting the addition of bank embezzlers, whose median take was but $\$ 3,410$.) The median for organizational offenders, which was nearly three and a half times the median in the subset of four, resulted from the addition to the sample of complex SEC frauds and the very few antitrust offenses where dollar magnitude data were available.

The mean take for individual crimes in our four offense subset was almost $\$ 75,000$, or about four times the median magnitude. The distribution was extremely skewed; a small number of cases involved gargantuan amounts. ${ }^{30}$

The mean value of a crime committed organizationally exceeded a million dollars. This contrasts with a little over half that much $(\$ 612,305)$ for our subset of four. As with the median, this difference largely reflects the presence of the SEC cases. The median take for persons convicted of SEC fraud was almost half a million dollars $(\$ 492,601)$. Twenty percent of these cases were in the $\$ 2.5$ million

30. The largest category in our magnitude coding system was $\$ 2.5$ million and over. We do not know the distribution of the cases in this sub-category. In calculating mean take, we used $\$ 3$ million as a conservative estimate for all such cases. Average magnitude in that category is probably somewhat larger. And this effect is present, of course, primarily for organizational offenses. Thus, we again feel the very large gap between the organizational and individual defendants probably understates the actual difference. 
and above category. And while data were available on only fourteen percent of antitrust violations surveyed, twelve of those sixteen cases were in the \$2.5 million-plus category, and the other four were worth over half a million dollars.

These data, though crude, point to the enormous advantage accruing to those who use formal organization. But the results might be due to other variables that are correlated with the organizational dimension. Can anything be said regarding the effect of organization on offense magnitude when other, arguably relevant, factors are held constant? We employed ordinary least squares regression to address the problem from this perspective.

We first considered variables that measured offense-specific characteristics, such as statutory category, frequency and duration, geographic spread, complexity, sophistication, and the defendant's use of an occupational role. Our attention next turned to offender traits, including the defendant's age, sex, race, level of education, arrest record, position within employing organization (whether or not such position was used to further the crime, or the organization was involved in illegal activity), occupational status, and "impeccability" or general community standing. ${ }^{31} \mathrm{~A}$ "best" model, reflecting attributes of both offense and offender - one which most accurately predicted offense size on the basis of such information - was estimated in this fashion.

Of the variables describing offense characteristics, duration, geographic spread, complexity, and sophistication were consistently significant at the very low alpha levels $(\mathrm{p}=.0001)$; a group of dummy variables representing crime categories were also statistically significant. The frequency of illegal acts and the defendant's use of an occupational position, however, were not. Of the offender traits, age, race, education, and prior record were found unimportant, but sex did prove a significant predictor of offense magnitude. This is perhaps misleading, given our sample; a large number of our female defendants were relatively lowly placed bank tellers convicted of embezzlement. ${ }^{32}$ Sex was therefore an offense-specific measure of sta-

31. For the occupational prestige ratings, see Duncan, $A$ Socio-Economic Index for $A l l O C$ cupations, in Occupations \& Soc. Status 109 (A. Reiss, Jr. ed. 1961). "Impeccability" was a composite of 29 background variables generally included in the presentence reports. These described early family life, academic performance, military and employment history, present living arrangements, religious attendance, group affiliations, involvement with drugs and alcohol, and community reputation.

32. $15.6 \%$ of the sample's defendants were women; nearly half of these women (47.6\%) were convicted of bank embezzlement, and only one of those held a position higher than teller or clerk. Ninety percent of all female defendants held nonmanagement jobs of that general rank. 
Table 6

\section{Predictors of Offense Magnitude}

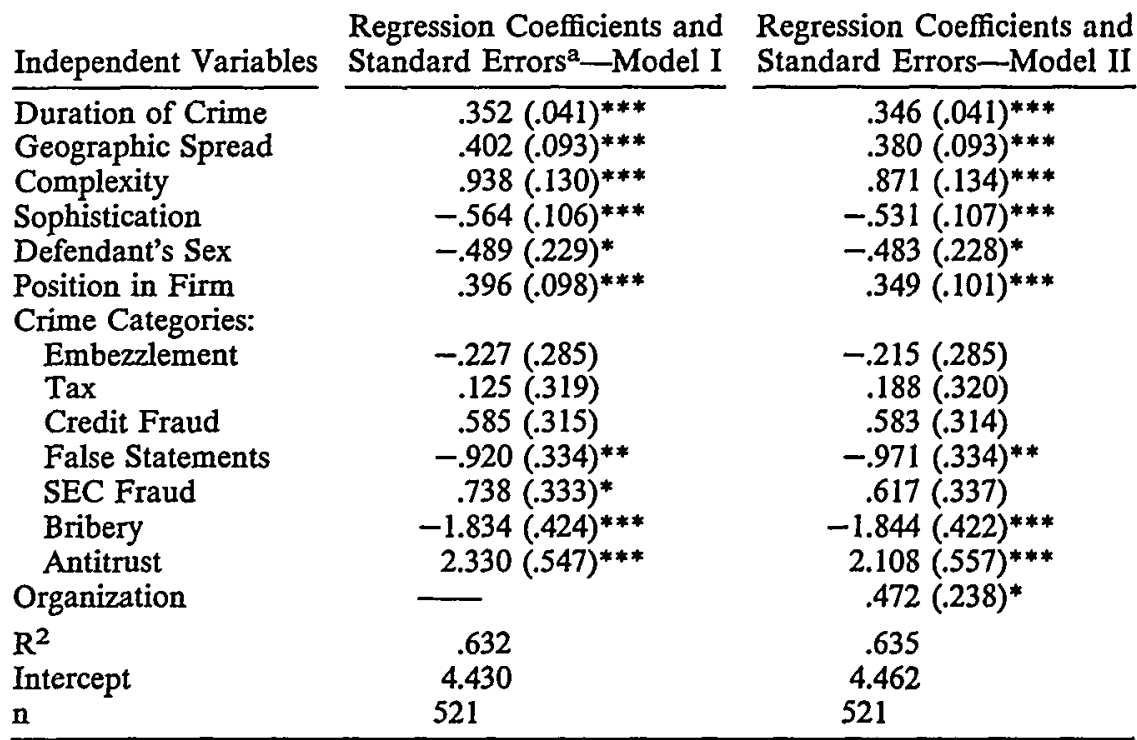

a: Standard errors shown parenthetically

*: p $.05^{* *}$ : p $011^{* * *}$ : p .001

tus as much as an indicator of valid gender-related differences in criminal activity.

Position in firm was the most important of the more obvious measures of social standing; one's company rank was always highly significant, whether or not occupational prestige or impeccability were also included in the model being tested. Prestige and impeccability were significant when each was alone in the equation, insignificant when position in firm was also present.

The best model in hand, a dummy variable reflecting whether the crime in question had been conducted through or with the assistance of a formal organization was added to this already-developed equation - to see if the fact of organization made any difference in offense magnitude, once other significantly related factors had been taken into account. Table 6 shows what happened: without disturbing the significance of factors already identified as material predictors of offense size, organization was also found statistically significant. The result lends considerable support to the conclusion we drew from Table 5 - the organization contributes in a very important way to the profits of white-collar crime. ${ }^{33}$

33. The organization variable was also added to equations in which occupational status and impeccability replaced position in firm. In the first instance, organization was significant at the $\mathrm{p}=.003$ level; in the second, at $\mathrm{p}=.0002$. 
A similar analysis was undertaken for our subset of four offenses. Though the results were largely the same, certain problems cloud interpretation. The defendant's use of an occupational role to effect or facilitate criminal activity was statistically significant; sex no longer was. While the variables describing the defendant's status were, in general, much less important, variation across judicial districts was now significant. ${ }^{34}$ Unfortunately, organization and the use of occupational role were too closely correlated in this subsample for us to weigh accurately the separate effects of each on offense magnitude. There are simply too many cases in which both organization and occupation are used for the regression technique to distinguish their respective contributions. When organization and occupation are introduced independently into a "core" model containing duration, geographic spread, complexity, and sophistication, they are both statistically significant. ${ }^{35}$ When they appear together, only occupation is significant at the traditional $\mathrm{p}=.05$ level (organization is significant at $p=.08$ ) - but given the nature of the cases we are studying, this statistical result cannot be taken to suggest substantive importance or the lack of same.

Why the organizational edge? Organizations, of course, operate on a grander scale than mere individuals. This difference can be illustrated most clearly by an example. In one case, an individual applied to the same bank for both a personal and business loan, offering phony personal tax returns as proof of his financial standing. The personal loan was for $\$ 10,000$; the corporate loan was for $\$ 150,000$. Neither was repaid.

A second loan case points to the same conclusion. Represented by its president, a corporation entered into a factoring agreement with a leading New York commercial bank, presenting it with $\$ 1.2$ million in false billings over the course of seven months; the company's statements were either inflated to reflect much more business than was actually being done, or were simply made up. Would the bank have done this for an individual? Whether we conclude that organizations are trusted more than individuals, or that they simply operate on a much larger scale, it is clear that the havoc caused when organizations are used ${ }^{36}$ outside the law far exceeds anything pro-

34. The effect of inter-district variation did not figure importantly in the larger sample in part because of the close relationship between crime category and judicial district.

35. Organization at $\mathrm{p}=.0002$, occupation at $\mathrm{p}=.0001$.

36. In the two cases just cited, as in most of our "organizational" offenses, crimes are not really committed by organizations, but are instead wrongs committed by individuals who use an organization as a base for illegal activity. 
duced by unaffiliated actors.

Magnitude of monetary loss is only one measure of consequence. An examination of the targets of white-collar crime provides another. Was the victim an organization, such as the bank in an embezzlement case or the government in a tax fraud? Or has some combination of organizations and individuals, or only individuals, been injured? When "real people" are hurt, trial judges often feel that a more serious violation has occurred. ${ }^{37}$ It is therefore worth examining the targets chosen by our three types of offenders. We do that in Table 7.

Table 7

Type of Victim

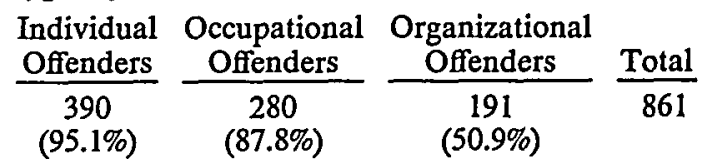

Organizations and Individuals,

Only Individuals

\begin{tabular}{cccc}
20 & 39 & 184 & 243 \\
$(4.9 \%)$ & $(12.2 \%)$ & $(49.1 \%)$ & \\
\hline 410 & $\frac{219}{319}$ & $\frac{1}{371}$ & $\frac{1104}{}$
\end{tabular}

Total

Perhaps the first finding we should recognize is that most victims
white-collar crime are organizations (including that largest of all organizations, the federal government). Just as the organizational form allows the commission of larger offenses, so organizations have more resources to be stolen, and in that sense are more appropriate targets for large-scale economic crime. It has also been suggested that organizations may be less able to defend themselves against criminal predation, again increasing the likelihood that they will be victimized.38 Beyond this the nature of the target of white-collar crime is sharply related to the type of offender. If the offender is an individual, or an individual working through an occupational role, the victim is almost certain to be an organization. As Table 6 shows, ninety-five percent of 410 individual offenders acted against organizational victims, as did eighty-eight percent of those using occupation in the commission of their crime. Individuals (as well as aggregations of organizations and individuals) are most often victim-

37. For further detail on the study, see Mann, Wheeler \& Sarat, Sentencing the WhiteCollar Offender, 17 AM. CRIM. L. REV. 4 (1980). This conclusion is drawn from an interview study of the perspectives of federal court judges on the sentencing of white-collar versus common crime defendants.

38. Shapiro, supra note 13 , at 8 . On organizations as victims generally, see Reiss, Forward: Towards a Revitalization of Theory and Research on Victimization by Crime, 72 J. CRIM. L. AND Criminology 704 (1981). 
ized by organizational offenders. A land fraud where individual victims lose their savings by investing in worthless property is a good example. Thus, not only are organizational offenders more likely to have committed much larger crimes in a monetary sense, they are also more likely to have victimized individuals, who are presumptively less able to recover from losses sustained.

That organizational crimes are regarded as more serious is supported by two further pieces of evidence. The first concerns the maximum "exposure time" that our convicted felons could have served for their offenses. This measure reflects in part the number of counts for which defendants were separately charged, as well as the maximum penalties that Congress has established for each offense. The maximum exposure time for individual defendants averaged four years and three months. For occupational and organizational defendants, the average was five years, two months and five years, three months, respectively. When we looked at our subset of four crimes to remove some of the offense-specific effects, the mean exposure time was five years, two months for individuals, six years and one month for occupational defendants, and six years and eight months for organizational defendants. Legislative judgment and judicial action, as well as actual defendant behavior, thus give strong evidence that organizational offenses are more menacing than occupational or individual crimes.

\section{The Nature of the Defendants}

Since organizational offenders commit offenses of greater duration, sophistication, magnitude, and perceived seriousness, one might imagine that they are to white-collar crime what the professional criminal is to blue-collar crime: namely, persons who have specialized in crime as a way of life. If so, we might expect to find that they have longer prior criminal records, and that they come from more deprived social backgrounds than the other defendants in our sample. Precisely the opposite is true. Because this Article seeks primarily to describe differences in the nature of the offense and its consequences, we will not examine in detail the disparities in defendants' social and criminal backgrounds. A summary portrait, however, includes the following main features:

(1) Organizational offenders are far less likely than their individual counterparts to have prior criminal records. The individual defendants had on average 3.4 prior arrests; the organizational offenders averaged slightly more than one half of one arrest, with the 
occupational offenders in between, but much closer to the organizational defendants.

(2) When organizational defendants did have prior records, their most serious prior convictions were much less important than those of individual defendants. ${ }^{39}$

(3) Although the average educational level for the total sample was quite high, it was about two years higher for organizational defendants than for individual ones, with occupational offenders precisely in between. (The mean years of education were: individuals, 12.2; occupational defendants, 13.2; organizational defendants, 14.0).

(4) Organizational defendants were significantly older, averaging forty-seven years for the total sample, as compared to forty years for the individual defendants. ${ }^{40}$

(5) On two different but related measures of social status, one reflecting occupational status, and the other the exemplary character or "impeccability" of the defendant's prior conduct, organizational defendants were again better positioned than their individual counterparts. They occupied higher positions when judged against standard occupational prestige ratings, and their prior conduct and community reputation looked much more "impeccable" than those of individual offenders. ${ }^{41}$ On both measures, defendants who used occupation fell between individual and organizational defendants, though they were far closer to the latter.

(6) Perhaps because of the traits just described, probation officers were more likely to give a positive characterization of the community reputations of organizational offenders in PSIs, than to so characterize the reputations of occupational or individual offenders. Such representations were made for fewer than ten percent of the individual defendants and fifteen percent of the occupational defendants, but appeared in the reports of twenty-three percent of the organizational defendants.

All of this suggests, then, that a portion of the organizational defendant's advantage accrues not through his organizational affiliation per se, but because the defendants' stature lends credibility to their claims. Occupational and organizational status tend to go to-

39. The coding scheme for most serious prior convictions was based upon New York's Penal Code, with minor additions for various federal offenses. There is a grading of offenses from misdemeanors through low, moderate and high felonies.

40. Here again there are offense-specific results. Because tax offenders tend to be older than embezzlers, our "occupational" category had a lower mean age (35) than the individual category when we examined the total sample. In the restricted sample, the numbers fell neatly into place: an average of 36 years for individual defendants, 41 years for occupational defendants, and 44 years for organizational criminals.

41. See note 31, supra. 
gether in our society - the stockbroker, for example, is also vicepresident of the firm and the lawyer is also general counsel to the corporation. This combination of organizational status and occupational position facilitates the theft of vastly greater sums of money than in the case of almost any other kind of crime, white-collar or not. Perhaps it is precisely the honorific status that we associate with the higher positions in social life - a reward for achievement and upstanding conduct - that enables the few in such positions who commit more serious crimes to gain so greatly from them.

\section{Sanctions and Legal Processing}

In a related paper on the sentencing of white-collar offenders, we note that the first and most important decision a sentencing judge makes is whether the defendant will be imprisoned. 42 We attempt here to trace the major correlates of that decision. Act-related variables such as dollar victimization, sophistication, geographic spread, and seriousness of the offense, as measured by maximum exposure to imprisonment, are significantly related to the decision to incarcerate. So are a number of actor-related variables: the social status of the defendant, as measured by Duncan socioeconomic index scores (a positive relationship), our measure of impeccability (the more impeccable, the less likely is incarceration), the number of previous arrests, and the most serious prior conviction. In addition, some of the variation in incarceration can be explained by the statutory offense category itself, by the district of conviction, and most important, by the sex of the defendant (women are much less likely to be imprisoned than men).

These various factors do not permit clear prediction of sentencing patterns for organizational versus individual and occupational offenders. On the one hand, the greater magnitude and sophistication of organizational offenders' crimes and their concomitant higher act-related variable scores should point to a greater rate of incarceration. But organizational offenders' actor-related variable scores, especially those relating to impeccability and prior criminal history, are lower than those of individual or occupational offenders, suggesting that they will be put behind bars less frequently. So perhaps it is not surprising to find that differences in the rate of incarceration among the categories of offenders were miniscule, especially between organizational and individual defendants. Forty-eight percent of the

42. See Wheeler, Weisburd, and Bode, Sentencing the White-Collar Offender: Rhetoric and Reality, forthcoming in the American Sociological Review, for a fuller description. (on file with the Michigan Law Review). 
individual defendants, thirty-eight percent of the occupational defendants, and forty-six percent of the organizational defendants served some time in jail or prison. It would thus appear that the greater severity of organizational defendants' crimes was offset at time of sentencing by a more upright record of prior conduct. This interpretation receives added support when it is recognized that the probation officer's evaluative assessments, as reported in the PSI, gave an edge to those defendants who could boast occupational or organizational affiliation. It is also consistent with another relevant fact: organizational defendants were about four times as likely to have a supporting letter in their file from someone in the community. Finally, while only two thirds of the individual defendants enjoyed private counsel, over ninety percent of the organizational defendants were so represented. Privately retained lawyers may be more effective in keeping their clients from behind bars than appointed counsel.

For organizational defendants who were imprisoned, however, the greater severity of their crimes had an impact. Among all incarcerated offenders, the average length of sentence for the individual defendants was nearly fifteen months. It was about the same fourteen and a half months - for occupational defendants, but was twenty-four and a half months for organizational criminals. ${ }^{43}$ It cannot be claimed, therefore, that defendants who used an organizational "cover" were given short, merely symbolic prison sentences.

\section{Discussion AND Conclusion}

The bulk of this Article has tried to establish that persons who commit offenses under the aegis of an organization are able thereby to commit crimes of greater sophistication, complexity, and magnitude. In the remainder of this Article, we will speculate on what it is about the organizational form that produces such differences in take, and also consider possible social policy consequences that might flow from this way of looking at white-collar crime.

But before dealing with various substantive interpretations, we must consider the possibility that the main results are, in effect, an artifact of law enforcement procedures. The organizational offenses

43. The $14 \frac{1}{2}$ month figure for occupational defendants does not include one fellow who was committed to the custody of the Attorney-General for observation and study pursuant to 18 U.S.C. $\$ 4208 \mathrm{~b}$ (now $\$ 4205 \mathrm{c}$ ), which requires that the maximum sentence of imprisonment prescribed by law be imposed, at least temporarily, until a study providing "more detailed information as a basis for determining the sentence" is obtained. That defendant was given 17 consecutive five-year sentences; the sentencing project never learned whether the 85-year term was later reduced. 
in our sample, it could be argued, are of large magnitude because those are the ones it pays to detect and prosecute. If organization provides effective cover for offenses, then only the largest will warrant the heavy investigative and prosecutorial resources that it takes to get convictions. We would then be comparing a more representative sample of individual offenses with a very special sample of organizational ones, and much of the difference in magnitude reported above would be explained by this fact. This explanation is consistent with "labeling theory" in sociology, and with some of the known facts about complex white-collar illegality.

Though the argument cannot be dismissed, it really cuts both ways. If organizational crimes are more complicated, more difficult to ferret out and prove, then the more complex and problematic they become, the less likely it should be that they will come to the attention of enforcement personnel, be thoroughly investigated, or be prosecuted to successful conclusion after indictment. Our results may therefore underestimate differences between organizational and other kinds of white-collar crime. The simple fact is that we really don't know, in the case of common crime, simple white-collar crime, or complex white-collar crime what the relationship is between the magnitude of the take and the likelihood of getting caught. We see no reason in principle for that relationship to differ greatly across types of crime, and we rather imagine that in both simpler and more complex offenses law enforcement officials must trade off their estimated likelihood of a conviction against the magnitude of the take. The same felt need to maintain a winning record, to favor cases that will conclude expeditiously with negotiated pleas of guilt, will obtain regardless of the form illegality takes. In any event, even though there may be some diminution of effect if the "enforcement artifact" argument is valid, we doubt very much that it would entirely wash away differences of the magnitude reported earlier in this Article. We thus feel the findings still warrant interpretation.

Perhaps it is simply a question of scale. Just as famed heist-man Willy Sutton robbed banks because "that's where the money is," our defendants might use the organizational form because it yields large sums. Business organizations operate on a grander scale than individuals. The management of a chain of supermarkets, for example, will be perceived as having a legitimate need for larger bank loans than a mom and pop grocery store. Similarly, while there is a plausible upper limit to the number of Medicaid claims that a doctor practicing individually can possibly handle, when claims are submitted in the name of a clinic, it is harder to determine what that upper 
limit might be. Scale also means broader geographic reach. An organization can sell its dry oil wells in many different cities at once; a lone con-man can concentrate on only a relatively few victims at a single time. Just as economies of scale permit a big organization to profit legitimately from its size, so other attributes of scale facilitate the commission of large-scale illegalities.

We imagine that a phenomenological feature operates here, too - persons view organizations as more substantial, more solid, more secure than individuals, and thus they may be less attentive to the risks of being duped or done-in. ${ }^{44}$ Even when this greater reservoir of faith in the organization does not exist a priori, the fine art of impression management may serve the organization equally well. A firm's offices may be decorated with the accouterments of success plush carpeting, large desks, and fine antiques - even though the company's product is virtually worthless. Symbols of success need not be physical. We learned of one instance in which a corrupt organization was able to delay its downfall by visibly playing up its use of a major investment banking firm. The organization must be all right, the public was led to perceive, if a leading firm was negotiating its bank loans. All the more so when, as in our other cases, the individuals acting on behalf of the organization are likely to present exemplary backgrounds.

In short, the organizational form itself, and public perceptions warped by image-making, combine to give the organization a heightened sense of legitimacy. This legitimacy attaches, we believe, whether the organization is designed, as in so many of our cases, to receive money from commercial enterprises or federal funding sources in response to false submissions, or whether it seeks to induce private individuals and other organizations to invest in or buy products at inflated prices. Just as the organizational form has facilitated economic and technological development on a scale far beyond that achieved by individuals, so that form has permitted illegal gains of a magnitude that men and women acting alone would find hard to attain.

Even if the organizational form does not protect against getting caught, it may so delay the process that the magnitude of offense continues to grow. We have the strong impression that the professional norms that protect lawyer-client confidences also protect relationships among those of accountants, investment banking firms and

44. Indeed, one might guess that the corporate form, in particular, has become so familiar a way of doing business that its absence might be some sort of warning sign. The advantages of incorporation are so obvious that one who proceeds without them might be thought ignorant or foolish - not a good bet for a loan, investment, or as a business collaborator. 
others involved in large financial transactions, and are thus likely to delay if not entirely inhibit the reporting of wrongdoing. The same features that give organizations initial credibility with individuals shield them from overly hasty complaint or investigation. Concerted ignorance on the part of original offenders may be matched by that among those professionals most likely to be drawn close to the activity in question. ${ }^{45}$

If all these advantages accrue to the individual who uses the organizational form for illegal gain, why isn't there even more crime committed with the organization as weapon? Part of the explanation is that large profits may be made through legitimate organizational activity. For whatever advantages organization provides, it remains the case that illegal behavior is found more often in newer, ${ }^{46}$ smaller, ${ }^{47}$ less profitable $e^{48}$ organizations on the margins of more central business networks..$^{49}$ In part for this reason, we doubt the capacity of increased penalties alone to have much influence on the kind of behavior we are studying. Some defendants, to be sure, act on the basis of a carefully weighed cost-benefit analysis. Others see no alternative to a desperate financial situation, and many doubt that they will be caught.

This leads us to believe that more thought should be given to alternative mechanisms of control. Is it possible, for example, to develop better warning signs that would indicate when a company is in financial trouble and, therefore, more likely to adopt illegal solutions to its problems? Given the power of the organizational form, should we create more windows into the organization so that outsiders can see more clearly what insiders are doing? Can we make better use of the accountants and lawyers whose presence lends legitimacy to organizational conduct? Maybe we can predict under what circumstances organizations will be more likely to violate the law. Perhaps more sophisticated indicators can be developed, allowing regulatory and other enforcement workers to focus all-too-limited investigative

45. On the social construction of cover-up, see Katz, Concerted Ignorance, 8 URBAN LIFE 295 (1979).

46. S. Shapiro, Detecting Illegalities: A Perspective on the Control of Securities Violations (1980) (unpublished doctoral dissertation, Department of Sociology, Yale University); and P. Yeager, The Politics of Corporate Social Control: The Federal Response to Industrial Water Pollution (1981) (unpublished doctoral dissertation, Department of Sociology, University of Wisconsin).

47. S. Shapiro, supra note 46.

48. Staw and Szwajkowski, The Scarcity-Munificence Component of Organizational Environments and the Commission of Illegal Acts, 20 AD. SCI. Q. 345 (1975); M. ClinARD \& P. YEAGER, CORPORATE CRIME (1980). (1956).

49. Kriesberg, National Security and Conduct in the Steel Industry, 34 Soc. ForCES 268 
resources in areas where they will be most effective. The IRS audits tax returns, individual and corporate, with a relatively refined sense of the chances of finding attempted evasion. Can agencies charged with the control of organizational wrongdoing accomplish the same thing when they review reports of compliance with environmental pollution permits, offering statements, and the like?

Before new control strategies are investigated, time might well be spent considering the impact of regulation on organizational illegality. Although crimes of great magnitude can continue month after month, often accompanied by missed opportunities for detection, we cannot estimate the net effects of changed rules or administrative procedures. Perhaps we now have the "right" amount of crime committed via the organizational form, in the sense that any further surveillance or control efforts might reduce organizations' capacity to grow and respond to new opportunities. The dollars that would go into internal management or external control might be better spent on other activities. The sheer magnitude, however, of the losses caused by organizational misbehavior is enough to suggest the contrary.

We began with an announced concern for the effect of occupation and organization on white-collar criminal activity. We have shown that although a criminal acting in an occupational role does enhance his "take," it is the combination of occupation and organization that yields the greatest payoffs. Occupation and organization are to the world of white-collar crime what the knife and gun are to street crimes. And just as we now have research that explores the consequences of different types of weapons for common crime, so may we anticipate a more detailed examination of the use of the organizational form in white-collar illegality. The areas for research are fertile. What are the most crucial features of organization for the commission of specific white-collar offenses? Can we develop the organizational equivalent of the ballistics unit for common crime to identify readily features that link characteristic attributes of organizational style to particular offenses? These and related questions are prompted by viewing the organization as the white-collar criminal's most powerful weapon. 